$2^{\text {"I }}$ ANNUAL INTERNATIONAL CONFERENCE

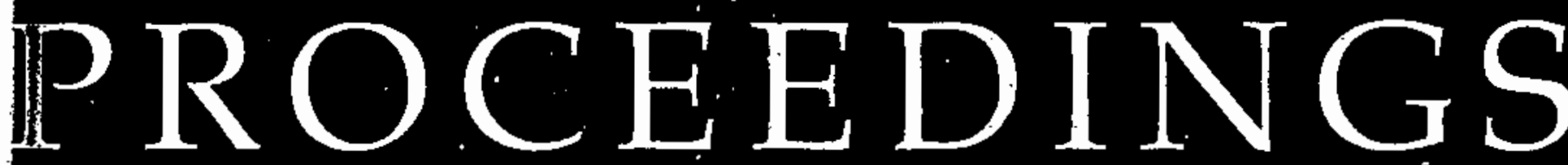

27 - 28 October 2014, Singapore

Pharmaceutical Sciences and Pharmacology (PHARMA 2014).
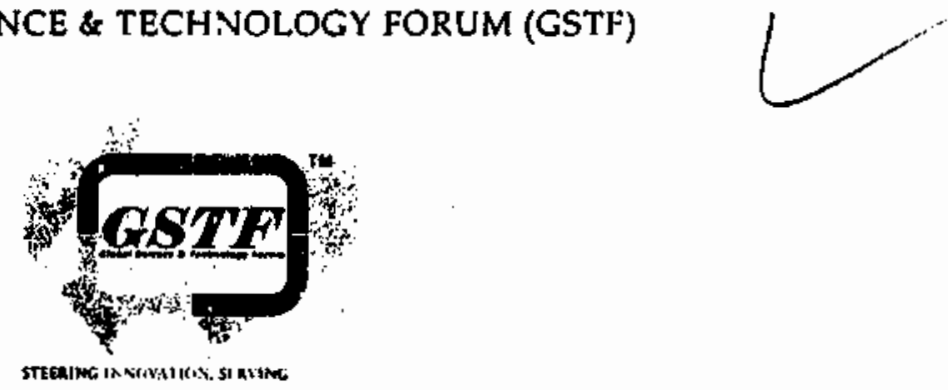

www.globalstf.org 


\section{Proceedings of the \\ 2nd Annual International Conference on Pharmacology and Pharmaceutical Sciences (PHARMA 2014)}

27- 28 October 2014

Singapore

\section{Organised \& Published By}

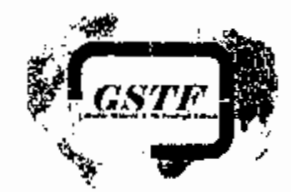


Organized, Published and Distributed by

Globai Science and Technology Forum (GSTF)

Pharmacology and Pharmaceutical Sciences PHARMA 2014

Tel: +6563270166

Fax: +6563270162

www.globalstf.org | info@globalstí.org

E-mail: secretariat@pharma-conf.org

Website: www.pharma-conf.org

Proceedings of the 2nd Annual International Conference on Phormacology and Pharmaceutical Sciences (PHARMA 2014)

ISSN: $2345-783 X$

This book, or parts thereof, may not be reproduced in any form, or by any means, electronic or mechanical, including photocopying, recording or any information storage and retrieval system now known or to be invented, without written permission from the Publisher.

Copyright $\circlearrowright$ GSTF 2014

All rights reserved.

Published by GSTF and indexed by EBSCO, CrossRef, Proquest, Ulrichsweb and will be submitted to Scopus, ScienceDirect, Cabell's Directory amongst others, where applicable.

The accuracy of all materials appearing in the paper as part or the proceedings is the responsibility of the authors alone. Statements are not necessarily endorsed by the organizers of PHARMA 2014, members of the Programme Committee or associated supporting organizations. 
It is my pleasure to present :.. you the Proceedings of 2 nd Annual Pharmacology and Pharmaceutica: Sciences (PHARMA 2014) organize Technology Forum in Singapore on 27 - 28 October 2014.

This conference serves as a forum for sctiolars, policy makers, ext enced professionals, and business executives to present and exchange new ideas on rest." in pharmacology and pharmaceutical sciences. The conference also is of interest to academ: sand industrialists of the related fields.

All the papers selected for presentation at this conference and for publication in the proceedings were subjected to double blind peer review.

We thank all review committee members, partner universities, organizing committee members, and especially all the conference participants for making this conference a grand success.

I am sure that the participants will benefit from the contributions to the Proceedings of PHARMA 2014 and trust that this volume will be useful in their future research endeavors.

Assoc. Prof. Dr, Wong Tin Wui PHARMA Editor-in-Chief Director of Non-Destructive Biomedical and

Pharmaceutical Research Centre Universiti Teknologi Mara, Malaysia 


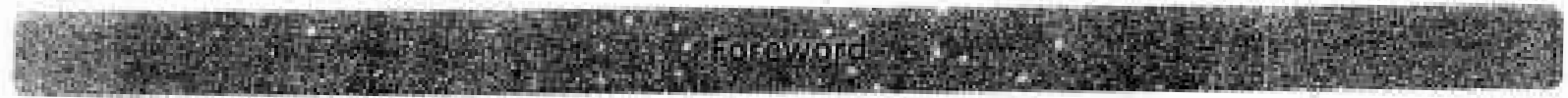

This volume of conference proceedings contains a collection of research papers presented at 2nd Annual International Conference on Pharmacology and Pharmaceutical Sciences (PHARMA 2014) organized by the Global Science and Technology Forum in M Hotel, Singapore on 27 - 28 October 2014.

The PHARMA 2014 conference is an international event for the presentation, interaction and dissemination of new advances relevant to pharmacology and pharmaceutical sciences. As member of the Board of Governors, GSTF, I would like to express my sincere thanks to all those who have contributed to the success of PHARMA 2014.

A special thanks to all our speakers, authors and delegates for making PHARMA 2014 a successful platform for the industry, fostering growth, learning, networking and inspiration. We sincerely hope you find the conference proceedings enriching and thought-provoking.

Professor the Hon. Dr. Stephen Martin Chairman, Board of Governors, GSTF 


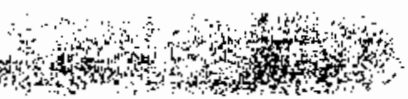

We are pleased to welcome you to the 2 nd Annual International Conference on Pharmacology and Pharmaceutical Sciences (PHARMA 2014) organized by the Global Science and Technology Forum in $M$ Hotel, Singapore on $27-23$ October 2014.

The PHARMA 2014 conference continuously aims to foster the growth of the research in pharmacology, pharmaceutical sciences and its benefits to the community at large. The comprehensive content of the conference has attracted immense attention and the wealth of information spread out over all the papers would be extremely useful to academics and professionals working in this and related fields.

It is my pleasure to announce the participation of leading academics and researchers in their areas of focus from various countries at this event. The Conference Proceedings and the presentations made at PHARMA 2014, is the end result of a tremendous amount of innovative work and a highly selective review process. We have received research papers from distinguished participating academics from various countries. There will be "BEST PAPER AWARDS" for authors and students, to recognize outstanding contributions and research publications.

I want to thank all authors for their participation. They have contributed a great deal of effort and creativity to produce this conference proceedings and I am happy that they chose PHARMA 2014 as the platform to present their work. Credit also goes to the Program Committee members and reviewers for their contribution in reviewing and evaluating the submissions and for making PHARMA 2014 a success.

Dr. Anton Ravindran President, Globol Science and Technology Forum Visiting Professor/Researcher, Institute for Research in Applicable Computing (IRAC). University of Bedfordshire, UK Adjunct Professor, Birla institute of Technology \& Science, Dept of Management (Pilani - Dubai Campus) Adjunct Professor, Department of Computing and information Systems, Bina Nusantara University 


\section{Program Chair}

Dr. Robert Vandenberg

Professor

Pharmacology, School of Medical Sciences

The University of Sydney, Australia

\section{Editor-in-Chief}

\section{Dr. Wong Tin Wui}

Director of Non-Destructive Biomedical and

Pharmaceutical Research Centre

Universiti Teknologi Mara, Malaysia

\section{Program Committee Members}

\section{Dr Crispin Dass \\ Professor, School of Pharmacy \\ Curtin University, Australia \\ Dr, Venkat Gopalakrishnan}

Professor \& Head, Department of Pharmacology

College of Medicine

University of Saskatchewan, Canada

Dr. Yashwant (Yash) Pathak

Professor and Associate Dean

for Faculty Affairs and Research,

Health College of Pharmacy

University Of South Florida, USA

\section{Dr. Shufeng Zhou}

Professor, Associate Vice President of Global Medical Development, Associate Dean of International Research, College of Pharmacy \& Morsani College of Medicine

University Of South Florida, USA

\section{Dr. Jun Ren}

Associate Dean for Research \& Professor of Pharmacology College of Health Sciences University of Wyoming, Laramie, USA

\section{Dr. Jonathan Blay}

Associate Director, Research and Graduate Studies Professor, School of Pharmacy

University of Waterioo, Canada
Dr. Zainol Akbar Zainal

Deputy Dean, Faculty of Pharmacy (Student Affair) Cyberjaya University, Malaysia

Dr. Grzegorz Sawicki

Professor, Department of Pharmacology University of Saskatchewan, Canada Dr. Sadia Sultan Faculty of Pharmacy, Universiti Teknologi MARA (UITM), Malaysia

\section{Dr. Anthony Tsarbopoulos} Associate Professor

Department of Pharmacology

University of Athens Medical School \& Director of Bioanalytical Department GAIA Research Center

The Goulandris Natural History Museum Athens, Greece

\section{Dr. Leslie Z. Benet}

Professor, UCSF School of Pharmacy Bioengineering and Therapeutic Sciences University of California, USA

Prof. Moses S.S. Chow Professor and Director College of Pharmacy FCCP 1985 American College of Clinical Pharmacy FCP 1988 American College of Clinical Pharmacology Western University of Health Sciences, USA 
Assoc. Prof. Xiaodong Feng

Associate Professor of Clinical \& Administrative Sciences

California Northstate University, USA

Assoc. Prof. Mariana Babayeva

Associate Professor,

Department of Pharmaceutical and Biomedical Sciences Touro university, USA

$$
\text { Dr. Gopal Pillai }
$$

Professor, Pharmaceutical Stiences Sullivan University, USA

Prof, Ram I. Mahato Head and Professor of Pharmaceutical Sciences

Department of Pharmaceutical Sciences College of Pharmacy University of Nebraska, USA

\section{Assoc. Prof. Carlos Feleder} Associate Professor

Department of Pharmaceutical Sciences Albany Campus Albany College, USA

Assoc. Prof. Arindam Basu Sarkar Associate Professor Pharmaceutical Sciences University of Findlay, USA

Assoc. Prof. David X. Liu Associate Professot, Pharmaceutical Sciences Washington State University USA

Prof. Nicholas Barnes Professor of Neuropharmacology School of Clinical and Experimental Medicine College of Medical and Dental Sciences University of Birmingham UK
Prof. Raid Alany

Professor of Pharmaceutics

Kingston University UK

Prof. John Howl

Professor, Molecular Pharmacology Research Group, Faculty of Science and Engineering University of Wolverhampton, UK

Prof. Patrick Ball

Professor of Pharmacy and Theme Leader Charles Darwin University, Australia

\section{Dr Heather Benson}

Associate Professor, School of Pharmacy Curtin University, Australia

Assoc, Prof. Christine R. Birnie Associate Professor and Chair, Department of Pharmaceutical Sciences St. John's Fischer Coliege, USA

Assoc. Prof. Fawry A. Elbarbry

Associate Professor

Pacific University, USA

Prof. Lisa E. Davis

Professor of Clinical Pharmacy

University of Sciences Philadelphia, USA

\section{Dr. D. Nagasamy Venkatesh}

Assistant Professor

Dept of Pharmaceutics

iss College of Pharmacy

(A Constituent College of JSS University, Mysore) Udhagamandalam, Tamil Nadu, India

Dr. Prashant Suresh Kharkar

Associate Professor and HOD of Pharmaceutical Chemistry M. Pharm. Sci., Ph.D.(Tech.)

NMiMS SPP School of Pharmacy and Technology Management, NMIMS Main Campus (Mumbai), India 
Editorial

Foreword

Prefoce

Program Committee

Author index

\section{2nd Annual International Conference on Pharmacology and Pharmaceutical Sciences (PHARMA 2014)}

\section{Pharmaceutics}

Design, Development and Evaluation of Ranolazine Loaded Chitosan Nanoparticles for Better AntiAnginal Therapy

D. Nagasamy Venkatesh

Metoprolol Tartrate Delivery from Mucoadhesive Buccal Tablet

Venkatalakshmi Ranganathan, Yeo Pei Xia, Gooi Mei Seong, Gan Li Ting and Ravi Sheshala

Evaiuation of in Vitro Release and in Vivo Transbuccal Permeation of Losarcan Potassium from Mucoadhesive Fllms

Marina Koland and Norayana Charyulu R.

Evaluation of Photoprotective Efficacy of Herbal Cream Against Ultraviolet Radiations Induced Photoaging in Mice

Ram Kumar Sahu, Amit Roy and Arvind Kumar Jho

Formulation and Characterization of Vesicular System for Transdermal Delivery of Aceclefenac Shashikant Chandrakar and Amit Roy

Effect of Lactose and Maltodextrin on The Physical Characteristics of Ovalbumin-loaded Alginate

Microspheres Produced By Aerosolization

Dewi Melani Hariyadi, Tutiek Purwanti and Rahma Nita Nirmala

Mucoadhesive Multiparticulate System of Ondansetron for Colon Targeting

Effect of Combining Both $\mathrm{pH}$ and Bacterial Enzyme Triggered Mechanism

Ashwin Thorot and Monju Misro

Solid Self Emulsified Drug Delivery of Exemestane Hyrdochloride

Bhupendra Prajapati 


\section{Physiology}

Influence of P.Glycoprotein on the Absorption of Nateglinide Through Rat Intestine Lla K. Nath and Nihar R. Pani

\section{Discovery}

Screening of Albizia lebbeck bark extract as a potential antivenom agent against Cobra Naja naja Smita Thube, Satej Katekar and Tosleem Kureshi

The Effects of Glyceryl Trinitrat in Different Experimental Models of Pain

Bohotin Catalina Roxana, Dondas Andrei, Alexa Teadora, Luca Andrei and Munglu Ostin Costel

The Effects of the Methylene Blue on Nocifensive Behaviours in Mice

Andrei Dondas, Teodora Alexa, Andrei Luca and Catalino Roxana Bohotin

Using Blodiversity for Discovering Potential Anti-Amyloidogenic Agents

Nikolaos Stavros Koulakiotis, Dimitrios Anagnostopoulos, Ioanna Chalatsa, Despina Sanoudou and Anthony Tsarbopoulos

\section{Toxicity}

Cytotoxicity of 17a-Azasteroids towards Liver and Neuroblastona Cancer Cell lines Neelima Dhingra and T.R.Bhardwaj

\section{Practice}

Combination Drug Therapy versus Single Drug Therapy

Zaheda Bano, P.N.Amaranath and Sk.Farida

"Diarrhea Care Program" as Effective Pediatric Diarrhea Counseling Tool for Pharmacy Practice 1. Camellia, H.R. Pramestutie and A. Hariadini 


\title{
Effect of Lactose and Maltodextrin on The Physical Characteristics of Ovalbumin-loaded Alginate Microspheres Produced By Aerosolization
}

\author{
Dewi Melani Hariyadi ${ }^{*}$, Tutiek Purwanti', Rahma Nita imala' \\ 'Airlangga University, Faculty of Pharmary, Pharmaceutics I ' sartment \\ Surabaya, Indonesia \\ - Email: dewiffua96@yahoo.com
}

\begin{abstract}
Abstraci- Effect of lactose and maltodextrin as potential jyoprotectants were examined. Encapaulation efficiency, protein loading and microspheres morphology were used as the parameter to evaluate the lyoprotectants. Scanning electron microscope was used to characterise the morphology of freezedried ovalbumin-losded alginate microspheres. Use of $2.5 \%$ concentration of alginate and ovalbumin were applied and $\mathrm{CaCl}_{2}$ was used as crosstinking agent. Maltodextring were found to protect ovalbumin-losded alginate microspheres stabilization during treeze-drying. The lyoprotection maltodextin formulations performed better stabilizer than those containing lactose. Hydrogel microspheres demonstrated almost round spherical particles. Freeze dried microspheres of maltodextrin formulations were spherical and smooth particles la addition to their smaller sizes (1-5pm). In the case of encapsulation efiiciency and protein loading of ovelbumin-losded alginate microspheres, high encapsulation efficiency and loading was observed and lyoprotection was improved by addition of $5 \%$ of maltodextrin as lyoprotectant. To conclude, maltodextrin could be consldered as potential lyoprotectonts in lyophillzation of proteins.

Keywords-ovalbumin; microspheres; Inctose; maltodextria; lyoprotectant.
\end{abstract}

\section{IrrTRODUCTION}

Studies of therapeutic proteins have been conducted widely to overcome problems with proteins [1]. In comparison with small molecule, peptides and proteins have. some disadvantages such as lower stability, faster deactivation, short half life and absorbtion problems when administer orally. Parenteral route has been chosen for many years, however oral administration is a favor route of drag or protein administration due to patient acceptability [1].

Ovalbumin is a model of protein consists of 385 amino acids which have antigenicity to increase immunity, however ovalbumin is a poor immunogenic therefore it needs to give frequently which may cause patient inconvenience [2]. Rudra et al have formulated ovalbumin in a controlled or delayed system [3].

Encapsulation is one of the drug delivery systems which potential to protect active material from extreme conditions

2nd Annual International Conference on Pharmacology and Pharmaceutical Sciences (PHARMA 2014)

Copyright @ GSTF 2014

ISSN $2345-783 \mathrm{X}$

doi: $10.5176 / 2345-783 \times$ PHARMA14.29 during formulation and administrations beside control its release [4].

Biodegradabel polymer have been used extensively to encapsulate protein and peptides by oral administrations [5]. Sodium alginate is a natural polymer having good biocompatibility, non toxic and widely used as polymer for microspheres [6].

Crosslinking agent is a cation that crosslink with alginate polymer to form microparticles, for examples $\mathrm{Ca}^{2+}$ or $\mathrm{Ba}^{2+}$. $\mathrm{Ca}^{2+}$ was selected as crosslinker due to its ability to form stable gel, non toxic and provide a significant stability in nicrospheres [6].

Several encapsulation methods have been investigated, for examples solvent evaporation and extraction, phase separation (coacervation), ionotropic gelation, interfacial polvmeration, spray drying. and supertitial fluid precipitation [7].

In our previous research, ionotropic gelation using aerosolisation technique was chosen as the best method to encapsulate ovalbumin [8]. This technique was affordable, simple, easy to produce, avoid use of organic solvent and efficient method.

Protejn problems have been known for many years in terms of stability during formulation, storage and transportation. Dried forms of protein delivery system was the best option for maintain stability of proteins. Lyophilization was one of the stabilization methods. This technique has been applied to avoid or slower protein degradation at room temperature [9].

This physical instability was mainly caused by aggregation or sedimentation of particles during formulation, therefore lyoprotectant agents have been added into microspheres formulation to stabilize the microspheres [10]. Freeze drying process is one of steps in drying of microspheres and addition cf lyoprotectants lactose and maltodextrin prior to this process was investigated in this study. This study aims to study the effect of lyoprotectants on the physical characteristics of ovalbumin-loaded alginate microspheres. 


\section{MATERIALS AND METHODS}

Materials

Ovalbumin phanmaceutical grade and Sodium alginste pharmaceutical grade, protein quantification kit were purcbased from Sigma-Aldrich Inc; $\mathrm{CaCl}_{2}, 2 \mathrm{H}_{2} \mathrm{O}$ pharmaceutical grade (Solvay Chemicals International); Sodium citrate pharmaceutical grade (Weifang Ensign Iadustry Co. Ltd.); Maltodextrin pharmaceutical grade and Lactose pharmaceatical grade were purchased from Bratachem, and Aquadest.

Methods

Formulation of micraspheres using aerosolisation technique

The alginate-ovalbumin solution was sprayed into cross linking agent solution and was stirred at $1000 \mathrm{mpm}$ for 2 hours. Lyoprotectant agents at concentrations of $5 \%$ were added into ovalbumin-loaded alginate microspheres. Microspberes were washed by centrifugation at $2500 \mathrm{rpm}$ for 6 minutes and washed twice using aquadest. Ovalbumin-loaded alginate microspheres were then collected and freeze dried at $-80^{\circ} \mathrm{C}$ for 20 hours.

\section{Infrared spectroscopy}

Infrared absorption measurements were carried out with an FT-IR spectrometer at room temperature. Spectra were recorded in a wave number range of 4,000 to $500 \mathrm{~cm}^{-1}$. A reference spectrum was measured prior to each experiment to correct the background effeets of all the spectra recorded. Briefly, sample of maltodextrin or lactose was mixed dried $\mathrm{KBr}$ powder and pressed under a vacuum using hydraulic pressure to obtain a transparent pellet. Spectra were then recorded.

\section{Encapsulation efficiency and protein loadings}

The ratio of the actual ovalbumit content in the proteinloaded microspheres to the theoretical ovalbumin content was termed encapsulation efficiency. For prutein loadings, accurately $50 \mathrm{~mL}$ of sodium citrate $\mathrm{pH} 8.5$ was added in 400 grams of microspheres and was continuously stirred at $1000 \mathrm{rpm}$ for 12 hours. The absorbance of ovalbumin was measured using UV Vis Spectrophotoinetry using protein quantification kit sigma at maximum wavelength of ovalbumin

\section{Scanning Electron Microscope (SEM) study}

The momhology of freeze-dried microsphere was observed after freeze-drying scanning electron microscope. The working distance was $10 \mathrm{~mm}$, beam energy was $20.0 \mathrm{kV}$, spot size was 5.0, and magnification was 5000 . The microspheres was loaded on a double sided carbon tape put on studs before being examined by SEM.

\section{RESULTS AND DISCUSSION}

The effectiveness of maltodextrin and lactose as lyoprotectant agent to prevent protein denaturation was evaluated during freeze-drying of the ovalbumin-loaded alginate microspheres. Since the protein denaturation during frecze-drying can aiter the functional properties of proteins, the evaluation of different type of lyoprotectants was important.

Lactose is disaccharides earbohydrate where according to Packheuser et al at $5 \%$ concentration resulted physical characteristics of stable microspheres [11]. Maltodextrin is selected because as the potential lyoprotectants on protein lyophilisation [12].

Fig 1 and 2 show obvious bonds indicated some functional groups of maltodextrin and lactose. However, interaction between lyoprotectant and alginate polymer need for further investigation.

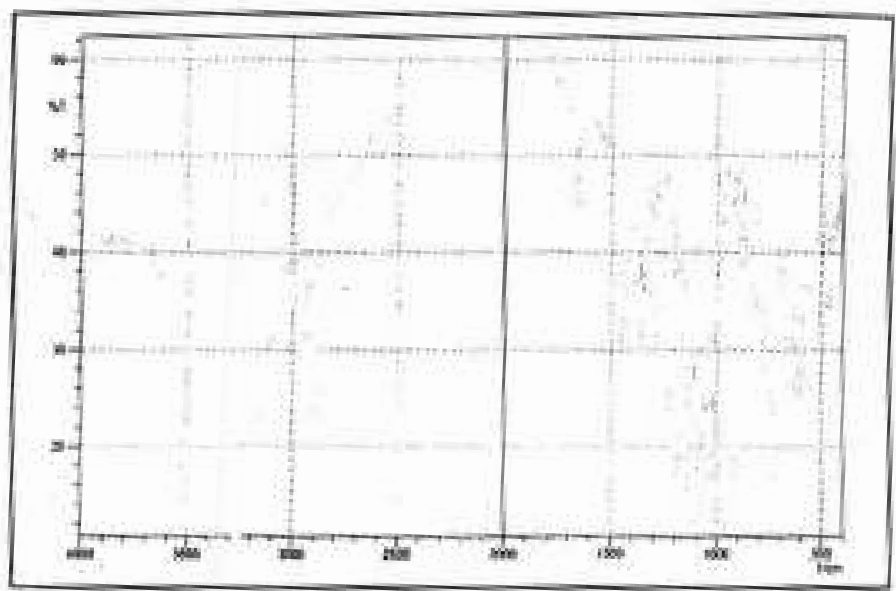

Figure 1. FTIR of lactose

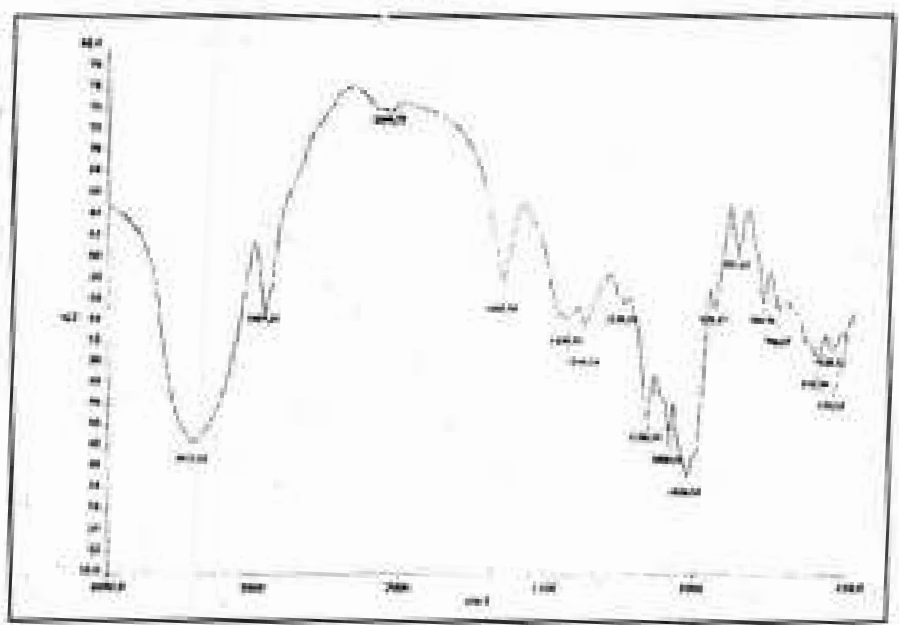

Figure 2. FTIR of maltodextrin

The results showed that the incomporation of lactose and maltodextrin as lyoprotoctants improved functional properties, due to the better physical characteristics of the ovalbumin. loaded alginate microspheres at concentration $5 \%$ wiv at -80 ${ }^{\circ} \mathrm{C}$ freeze drying condition. The encapsulation efficiency and ovalbumin loading had a marked dependence on the type of 
protectants used (Fig. 3). For good protectant, maltodextrin $(5 \%)$, the improvement attributed to higher protein encapsulation (56\%) and protein loading at about $50 \%$. Whereas the use of lactose at $5 \%$ concentration, less encapsulation efficiency and protein loading was noteworthy.

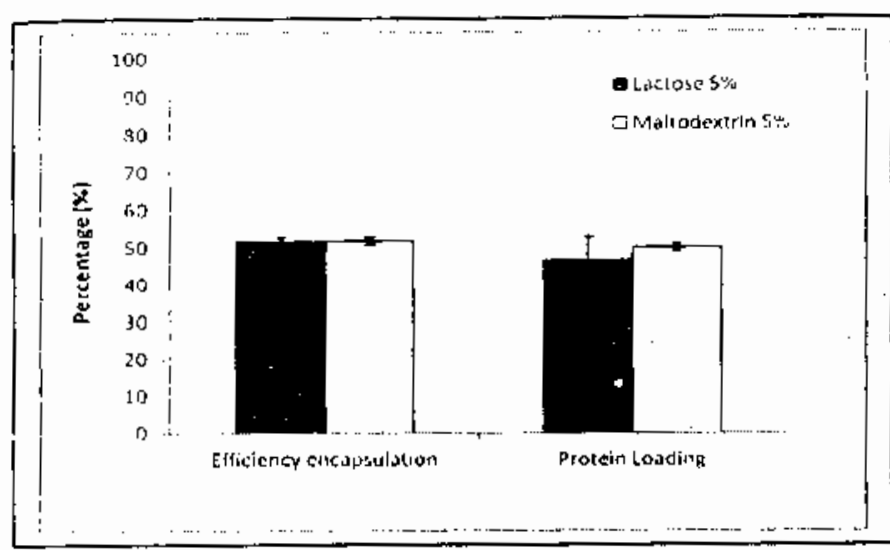

Figure 3. Efficiency encapsulation and protein loading of Ovalbumin-loaded alginate microspheres

The addition of lyoprotectant prior to lyophilisation resulted in a homogenous powder in regard to the blank (Fig.4). As expected, hydrogel alginate microspheres obtained with maltodextrin and lactose yielded homogeneous and spherical microspneres during optical microscopy examination (Fig.5).

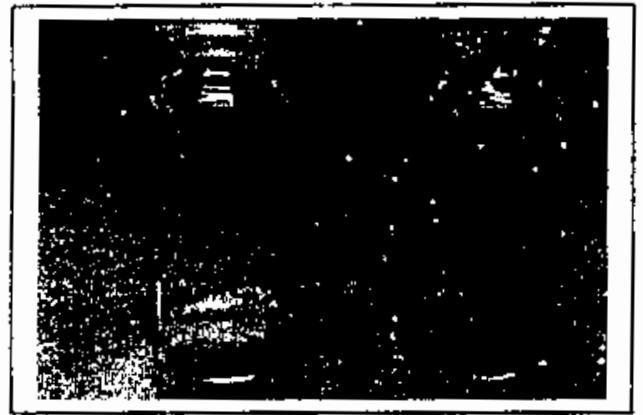

Figure 4. Photographs of freeze-dried ovalbumin loaded alginate microspheres A: maltodextrin as lyoprotectanc B: lactose as lyoprolectant
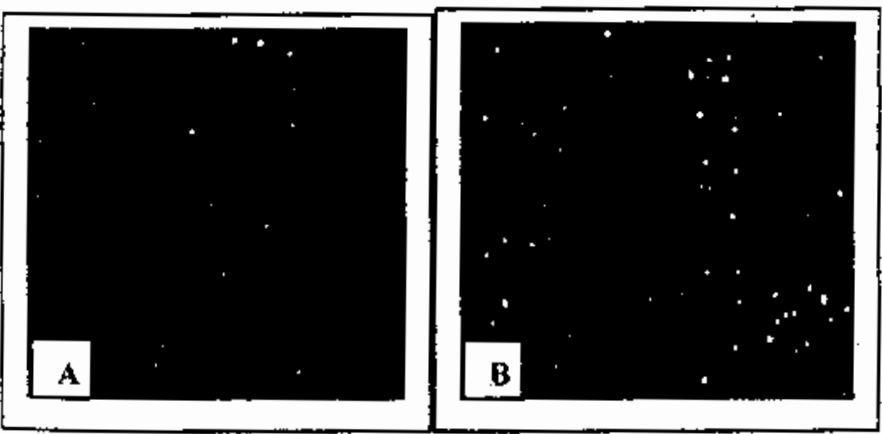

Figure 5. Hydrogel Ovalbumin-loaded alginate microspheres A: maltodextrin as lyoprotectant; B: lactose as lyoprotectant
The SEM micrographs revealed the formation of smooth, small and spherical microspheres with maltodextrin incorporation ( $F, g, 6)$. The incorporation of maltodextrin might lead to a product with more uniform, smaller and homogeneous pore structures. This fact was in agreement with other authors who indicated that saccharides lyoprotectant stabilizec bovine plasma protein [13]. Furthermore, the microspheres size was found to be $1.5 \mu \mathrm{m}$ using SEM examination.

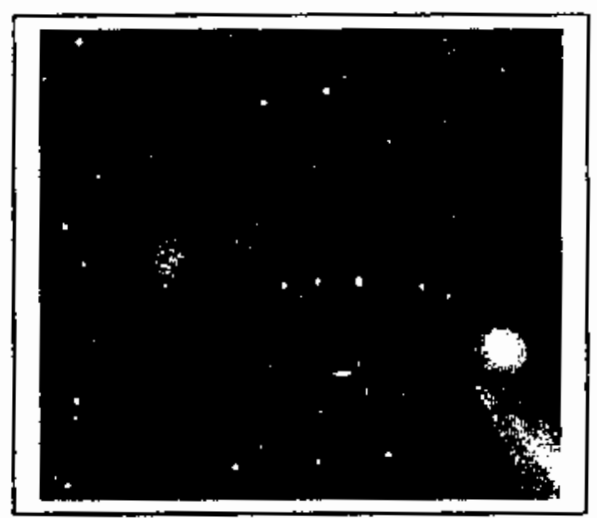

Figure 6. SEM of freeze-dried ovalbumin-joaded alginate microsplieres witts maltodextrin as lyoprocectan

Possible mechanism of maltodextrin in stabilizes ovatbumin loaded alginate microspheres maybe hydrogen bonding between sugar or alcohol sugar and protein as an important factor during freeze drying [14].

\section{CONCLUSIONS}

Maltodextrin at concentration of $5 \%$ were found to be better lyoprotectant agent on the ovalbumin-loaded alginate microspheres than $5 \%$ lactose. High encapsulation efficiency and loading were produced successfully by aerosolisation technique of alginate polymer and $\mathrm{CaCl}_{2}$ crosslinking agent Smail, smooth and spherical microspheres were also confirmed on the freeze-dried microspheres using $5 \%$ maltodextrin. Future research can focus on using different concentration of lyoprotectants.

\section{REFERENCES}

(I) Zhigang Ycng, Hangiun Pan, Hongxiang Sun, "The immune response and protective efficacy of oral alginate microparticle Aeromonas sobria vaccine in soft-shelied autles (Jrionyx sinensis)", Veterinary Immunology and Immunopathology, Vol. 119, pp.299-302, 2007.

[2] O'hagan DT. Rahman D. Mcgec JP. Jefery H. Davies MC. Williams P. Davis SS. and Challacombe SJ., "Biodegradable microparticles as controlled release antigen deiivery systems", immunology, pp.239.242 I991.

[3] A. Rudra, K. Santra and B. Mukherjee, "Paly (D, L-lactide-co-glycolide) Microspheres as a Delivery System of Protein Ovalburnin Used as a Model Protein Drug". Trends in Applied Sciences Research, Vol. 6(1), pp. 47.56, 2011 
[4] Bimbaum DT, Brannon-Peppas L., "Microparticle dnug delivery systema" In: Brows DM, edicor. Drug delivery aystems is cuncer therapy. Totowa: Hamana Press inc; 2003, pp.117-116.

[5] Martins S., Sammento B, Ferrein DC, and Sovvo EB, "Lipid-based colloidal carriers for percids and proteis delivery - tliposomes versus lipid nanogarticles", int $j$ Nanomedicine, Vol: 2(4), pp, 595-607, 2007,

[6] Conadie, T. Livage, 1. "Synthesis and Characterization of AlginaseiSilica Biocomposites." Joumal of Sol-Cal seience and Technolegy, Vol 25 (1-3), pa. I165-1168, 2003.

(7) Erdinc, Burak t. "Micro/Nanoeneapsulation of Proteins Wyithin Alginate/Chitosan Matrix by Spray Drying, "2007, pu. 12

[8] Hariyadi DM, Hendradi E., Purwaoti T, Fadit FDGP, Remadani CN, "EFFECT OF CROSS LINKING AGENT AND POLYMER ON THE CHARACTERISTICS OF OVALBUMEN LOADED ALGINATE MICROSPHERES", UPPS, vol 6 , issue 4, 2014.

[9] Carpenter, J.F., Pikal, M.S., Chang, B.S. Randolph, T.W, "Raticeal design of mable lyophilizod provein formalations: seme proctical advice", Pham. Res. Vol. 14, pp. 969-975, 1997

[10] T. Musumeci, L Vicari, C. A. Ventura, M. Gulisace R. Pignatello, and G. Puglisi, "Lyoprotocted Nanosphere Formulations for Paclitaxel
Controlied Delivery, Journal of Nanoscience and Nanotectinology, Vol.6, p9. $1=8,2006$

[II] Clevidis B. Packlaeuser, Kerstin Lahnstein, Johannes Sicterberz Thomas Schmeh. Tobies Gessier, Udo Bakowiky, Wemer Seeger, and Toomas Kirsell, "Stabilization of Aerasoliznble Nano-carriers by Freeze. Erying", Pharmactutica! Researeh, Vol. 26, Na I, . pp. 129.138, Drying", Phary 2009

[12) Corveleyn S., Remon 1.P. Malhodextrias a lyoprotestancs in the lyophitization of a modet procein, LDK", Pharmaceutieal Research. vol.13, pp. 146-150.

(13) Wei Wang. "Lyapt ration and developmest of solid provein pharmaceuticals", bien vional Journal of Ptarmaceutics, Vol. 203, pp. $1-60,2000$.

[14] Lanun T. Rodriguez Velin, Pamela Aldtele Herrera, Antonio Ptrez Padilla, Rosa I. Onir litururto, Mercedes E. Campdernda."' Assessment of agave fructans an lyoprotectants of bowne plasma proteins concentrated by whinfiltrabion," Food Researth Intersatianal, Vol.56, pp. $146-158.2014$ 
A. Hariadini

Alexa Teodora

Amit Roy

Andrei Dondas

Anthony Tsarbopoulos

Arvind Kumar Jha

Ashwin Thorat

Bhupendra Prajapati

Bohotin Catalina Roxana

D. Nagasamy Venkatesh

Despina Sanoudou

Dewi Melani Hariyadi

Dimitrios Anagnostopoulos

Dondas Andrei

\section{Gan Li Ting}

Gooi Mei Seong

H.R. Pramestutie

loanna Chalatsa

1. Camellia

Lila K. Nath

Luca Andrei

Manju Misra

Marina Koland

Mungiu Ostin Costel

Narayana Charyulu R.

Neelima Dhingra

Nihar R. Pani

Nikolaos Stavros Koulakiotis

P.N.Amaranath

Rahma Nita Nirmala

Ram Kumar Sahu

Ravi Sheshala

\author{
PHARMA-27 \\ PHARMA-28, 30 \\ PHARMA-47, 48 \\ PHARMA-30 \\ PHARMA-54 \\ PHARMA-47 \\ PHARMA-32
}

PHARMA-07

PHARMA-28, 30

PHARMA-33

PHARMA-54

PHARMA-29

PHARMA-54

PHARMA-28

PHARMA-51

PHARMA-51

PHARMA-27

PHARIMA-54

PHARMA-27

PHARMA-34

PHARMA-28, 30

PHARMA-32

PHARMA-26

PHARMA-28

PHARMA-26

PHARMA-42

PHARMA-34

PHARMA-54

PHARMA-49

PHARMA-29

PHARMA-47

PHARMA-51
Satej Katekar

PHARMA-09

Shashikant Chandrakar

PHARMA-48

Sk,Farida

PHARMA-49

Smita Thube

PHARMA-09

T.R.Bhardwaj

PHARMA-42

Tasleem Kureshi

PHARMA-09

Tutiek Purwanti

PHARMA-29

Venkatalakshmi Ranganathan

PHARMA-51

Yeo Pei Xia

PHARMA-51

Zaheda Bano

PHARMA-49 


\section{GSTIPARTNER UNIVERSITIES}
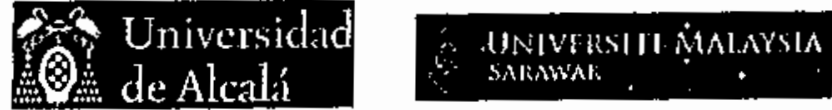

UR umivensity or arkansas

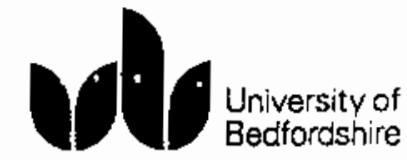

Bedfordshire
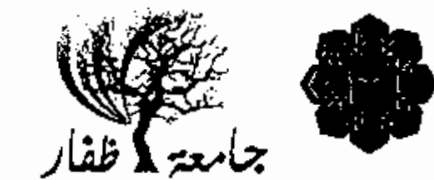

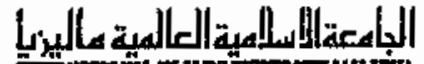

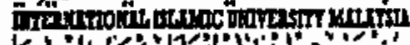

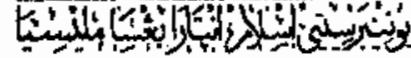

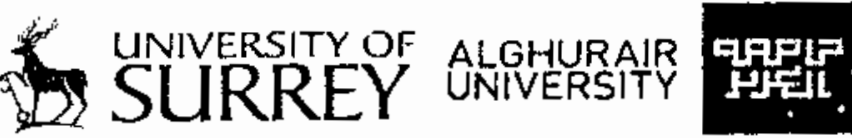
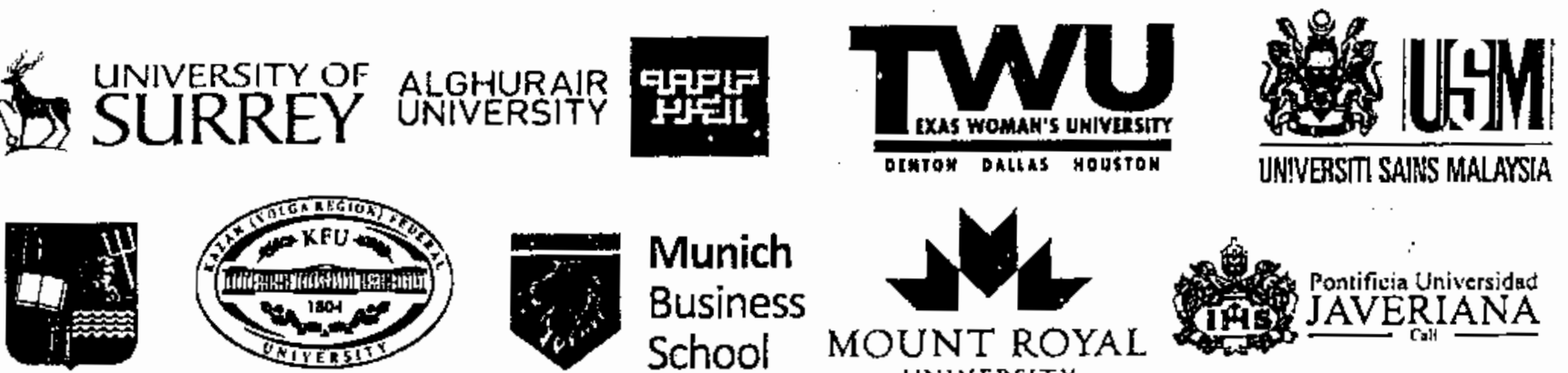

Munich

Business

School

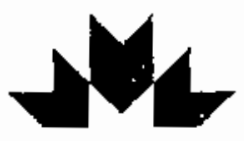

MOUNT ROYAL

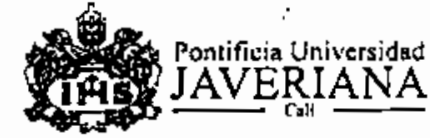
UNIVERSITY

\section{NYIT}

NEW YORK INSTITUTE OF TECHNOLOGY

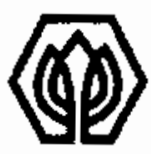

ปหาวิกยาละยครัปทน

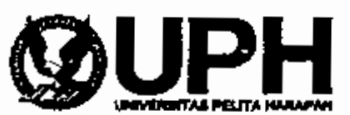

Glotal Purepective, Glotal Cempun.

SAA

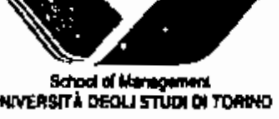

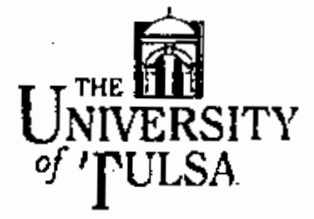

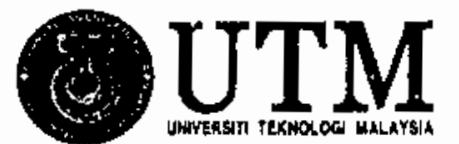

M

WASHINGTON \& JEFFERSON

UNDTHE SNIVEESTYKOR
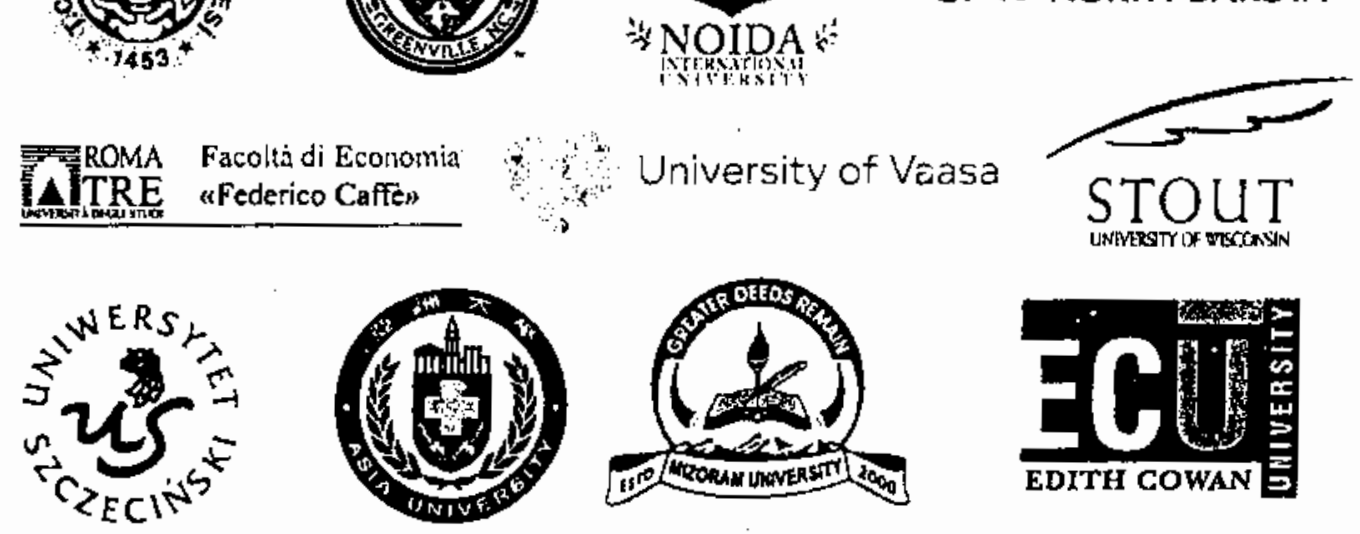

GSTF Conference Proceedings, published in print and electrunic format, are indexed by EBSCO, CrossRef, Ulrichsweb, ProQuest, PsyeEXTRA and will he submitted to Scopus, ScienceDirect and Cabell's Directories amongst others, where applicable.

The proceedings will be made avallable at GSTF Digital Liblary http://dl4.globalstforg 


\section{UNIVERSITAS AIRLANGGA \\ FAKULTAS FARMASI}

Kampus B J. Dharmawangs Dalam, Surabaya 60286 Telp. $031-5033710$ Fax. 0315020514

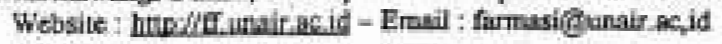

\section{SURAT T UGAS}

Nomor: $2974 / \mathrm{UN} 3.1 .5 / \mathrm{KP} / 2014$

Yang bertanda tangan di bawah ini :

$\begin{array}{ll}\text { Nama } & \text { : Junaidi Khotib, S.Si,M.Mes.,Ph.D } \\ \text { NIP } & \text { : } 19701022 \text { 199512 } 1001 \\ \text { Jabatan } & \text { Wakil Dekan II Fakultas Farmasi } \\ & \text { Universitas Airlangga }\end{array}$

dengan ini menugaskan kepada :

$\begin{array}{ll}\text { Nama } & \text { : Dewi Melani Hariyadi, S.Si.,M.Phil.,Ph.D.,Apt } \\ \text { NIP } & \text { : } 197802262002122 \text { 001 } \\ \text { Jabatan } & \text { Dosen Fakultas Farmasi } \\ & \text { Universitas Airlangga }\end{array}$

Untuk melakukan presentasi oral pada kegiatau "Anmual International Conference on Pharmacology and Pharmaceutical Science (PIAARMA 2014)" pada tangga! 26 - 29 Oktober 2014 di Hotel M Millenium Singapore.

Demikian Surat Penugasan ini untuk dilaksanakan dengan baik dan penuh tanggung jawab.

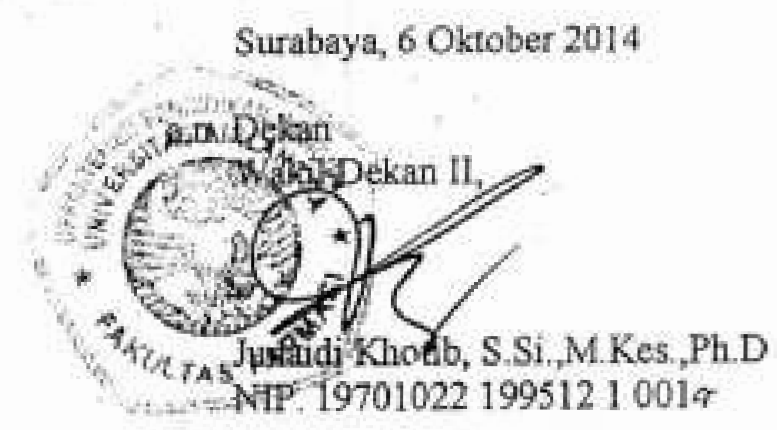


$2^{\text {ND }}$ ANNUAL INTERNATIONAL CONFERENCE

ON

PHARMA 2014

Pharmacology and Pharmaceutical Sciences

\title{
PRESENTED \& PUBLISHED
}

\author{
by \\ Dr. Dewi Hariyadi
}

Effect of Lactose and Maltodextrin on The Physical Characteristics of Ovalbumin-loaded Alginate Microspheres Produced By

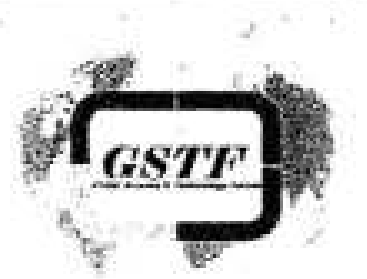

Date: 27 - 28 October 2014 Venue: Singapore

\section{Aerosolization}

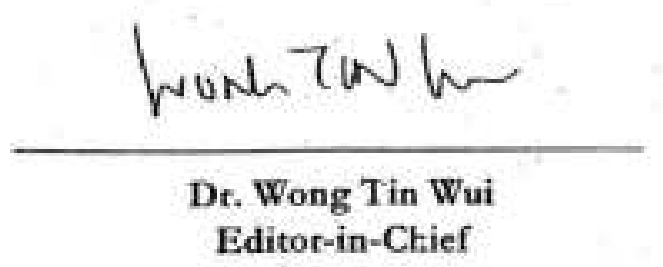

1. Antor Rowidial

Dr. Anton Ravindran President, GSTF 